\title{
Keratinocytes derived from late-onset psoriasis skin do not impair Langerhans cell migration
}

DOI:

10.1111/bjd.16896

\section{Document Version}

Accepted author manuscript

Link to publication record in Manchester Research Explorer

\section{Citation for published version (APA):}

Eaton, L. H., Dearman, R. J., Kimber, I., \& Griffiths, C. E. M. (2018). Keratinocytes derived from late-onset psoriasis skin do not impair Langerhans cell migration. The British journal of dermatology, 179(5), 1208-1209. https://doi.org/10.1111/bjd.16896

\section{Published in:}

The British journal of dermatology

\section{Citing this paper}

Please note that where the full-text provided on Manchester Research Explorer is the Author Accepted Manuscript or Proof version this may differ from the final Published version. If citing, it is advised that you check and use the publisher's definitive version.

\section{General rights}

Copyright and moral rights for the publications made accessible in the Research Explorer are retained by the authors and/or other copyright owners and it is a condition of accessing publications that users recognise and abide by the legal requirements associated with these rights.

\section{Takedown policy}

If you believe that this document breaches copyright please refer to the University of Manchester's Takedown Procedures [http://man.ac.uk/04Y6Bo] or contact uml.scholarlycommunications@manchester.ac.uk providing relevant details, so we can investigate your claim.

\section{OPEN ACCESS}


DR LAURA H EATON (Orcid ID : 0000-0003-0428-7291)

Article type : Research Letter

Keratinocytes derived from late-onset psoriasis skin do not impair Langerhans cell migration

\author{
L. H. Eaton, R. J. Dearman, I. Kimber, C. E. M. Griffiths
}

Corresponding author:

Christopher Griffiths

The University of Manchester

Manchester Academic Health Science Centre

Salford Royal NHS Foundation Trust

Manchester

M6 8HD

Christopher.Griffiths@manchester.ac.uk

\title{
To the editor
}

Chronic plaque psoriasis (CPP) is associated with over-expression of interleukin (IL)-17 and systemic antibody therapies targeting this cytokine are highly efficacious ${ }^{1}$. Psoriasis presents as either earlyor late-onset disease (before or after 40 years of age, respectively). Langerhans cells (LC) are the dendritic cells of the epidermis that regulate cutaneous immune responses ${ }^{2}$. In the uninvolved skin of early-onset CPP there is impaired LC migration after exposure to a contact allergen, tumour necrosis factor- $\alpha$ (TNF- $\alpha$ ) or IL-1 $\beta$ in vivo ${ }^{3}$. However, in late-onset psoriasis there is impaired migration in response to TNF- $\alpha$, but normal responses to IL-1 $\beta^{4}$. We have recently shown that in early-onset psoriasis, LC migration is impaired as a result of IL-17A causing changes in the psoriasis

This article has been accepted for publication and undergone full peer review but has not been through the copyediting, typesetting, pagination and proofreading process, which may lead to differences between this version and the Version of Record. Please cite this article as doi: $10.1111 /$ bjd.16896

This article is protected by copyright. All rights reserved. 
keratinocyte secretome ${ }^{5}$. Here we sought to examine whether keratinocytes isolated from uninvolved late-onset psoriasis skin also impair LC migration.

Volunteers were aged 18-65 years and either healthy with no history of skin disease or had psoriasis that first presented at age 40 or later; all provided $6 \mathrm{~mm}$ skin punch biopsies. The study was approved by the NRES Committee Northwest (13/NW/0867) and was conducted according to the Declaration of Helsinki and all subjects provided written, informed consent. To investigate LC migration ex vivo we utilised an epidermal explant model, described previously ${ }^{6}$. Firstly we wished to determine levels of LC migration in this model in late-onset psoriasis. Briefly, two skin biopsies were taken and one epidermal sheet was fixed immediately (TO) and the other cultured for $24 \mathrm{~h}$ (T24). We compared LC frequency in the T0 and T24 epidermal sheets and calculated LC migration in the T24 compared with the TO epidermal sheet for the same volunteer. There was a significant reduction in LC frequency in the late-onset psoriasis T24 epidermal sheets (Figure 1a). When comparing the percentage migration data for late-onset volunteers to historical healthy data there was no significant difference between groups (Figure $1 \mathrm{~b}$ ). To examine the effect of late-onset psoriasis keratinocytes on LC migration we generated conditioned media from healthy and late-onset psoriasis keratinocytes according to a method described previously ${ }^{5}$. We used this conditioned media in the healthy epidermal explant model to determine the effect on LC migration. In the EpiLife media control there was a significant reduction in LC frequency in the T24 cultured epidermal sheet (Figure 1c). Likewise, when epidermal sheets were cultured with healthy keratinocyte conditioned media there was significant loss of LC from the epidermis (Figure 1d). The same was true for epidermal sheets cultured in late-onset psoriasis keratinocyte conditioned media (Figure 1e). When comparing percentage LC migration between the three groups there was no significant difference in migration levels (Figure 1f).

Our data show that, in an ex vivo explant model LC migration in late-onset psoriasis uninvolved skin was normal, further confirming that LC function can be used to distinguish between the two ages of onset of psoriasis. As in vivo TNF- $\alpha$ doesn't stimulate LC mobilisation in late-onset psoriasis skin, it is likely that it may play a lesser role in this sub-type of the disease. We have previously shown, in a mouse model, that TNF- $\alpha$ is not always required for LC migration ${ }^{7}$. There are known changes in IL1 $\beta$ in late-onset psoriasis ${ }^{8}$, and therefore it is possible that IL-1 $\beta$ may play a more dominant role than in early-onset. Unlike early-onset, late-onset psoriasis keratinocytes don't secrete a factor that inhibits healthy LC migration. These findings confirm our previous observations that early and late-onset psoriasis can be distinguished based on epidermal LC function ${ }^{4}$. Our previous findings have shown that over-expression of IL-17A can inhibit LC migration probably due to an alteration of the keratinocyte secretome ${ }^{5,6}$. As conditioned medium generated from late-onset keratinocytes is unable to impair LC migration, it is likely that late-onset psoriasis may not have the same IL-17 pathology, at least in the uninvolved skin. Further studies should examine whether late-onset psoriasis is associated with over-expression of IL-17 as this could have consequences for treatment, in particular the use of anti-IL-17 therapies. Taken together, our results show that late-onset psoriasis keratinocytes have a phenotype that is distinguishable to that of early-onset disease which in turn produces significant differences in LC mobilisation. This may have relevance both to the pathology of psoriasis as LC are important in regulating the skin immune response and in the manner that these two subsets of the disease are managed.

This article is protected by copyright. All rights reserved. 


\section{Acknowledgements}

The British Skin Foundation for funding (Project Number: 7017). We would like to thank Jean Bastrilles, Marie Durkin, Rebekah Swan, Gill Aarons and Dr Elina Theodorakopoulou for volunteer recruitment and biopsy procurement.

CEMG is a National Institute for Health Research Senior Investigator

\section{References}

1 Chiricozzi A, Krueger JG. IL-17 targeted therapies for psoriasis. Expert opinion on investigational drugs 2013; 22: 993-1005.

2 Seneschal J, Clark RA, Gehad A et al. Human epidermal Langerhans cells maintain immune homeostasis in skin by activating skin resident regulatory T cells. Immunity 2012; 36: 873-84.

3 Cumberbatch M, Singh M, Dearman RJ et al. Impaired Langerhans cell migration in psoriasis. The Journal of experimental medicine 2006; 203: 953-60.

4 Shaw FL, Cumberbatch M, Kleyn CE et al. Langerhans cell mobilization distinguishes between early-onset and late-onset psoriasis. The Journal of investigative dermatology 2010; 130: 1940-2.

5 Eaton LH, Mellody KT, Pilkington SM et al. Impaired Langerhans' cell migration in psoriasis is due to an altered keratinocyte phenotype induced by interleukin-17. The British journal of dermatology 2017.

6 Eaton LH, Dearman RJ, Kimber I et al. Interleukin-17 and interleukin-23 regulate Langerhans cell migration. The British journal of dermatology 2016.

7 Eaton LH, Roberts RA, Kimber l et al. Skin sensitization induced Langerhans' cell mobilization: variable requirements for tumour necrosis factor-alpha. Immunology 2015; 144: 139-48.

8 Hebert HL, Bowes J, Smith RL et al. Polymorphisms in IL-1B distinguish between psoriasis of early and late onset. The Journal of investigative dermatology 2014; 134: 1459-62.

\section{Figure Legends}

\section{Figure 1 No impaired Langerhans cell migration in a late-onset psoriasis explants model}

Two $6 \mathrm{~mm}$ punch skin biopsies were taken from the uninvolved skin of patients with late-onset (presenting age 40 or over) chronic plaque psoriasis. Epidermal sheets were isolated and one was fixed immediately (TO). The other was cultured by floating on RPMI media for $24 \mathrm{~h}$ before fixing (T24). The LC frequency in epidmeral sheets was determined, each line represents one volunteer (a). The significance of differences was analysed by paired $t$ test, ${ }^{* * *} p<0.001$. (b) The percentage LC migration was calculated as a reduction in the T24 cultured epidermal sheet compared with the TO sheet for the same volunteer. Historical healthy data is shown as a comparison. The significance of differences between groups was analysed by $t$ test but was not significant.

Conditioned media was generated from healthy $(\mathrm{H})$ and uninvolved late-onset psoriasis (LOP) keratinocytes $(K C), n=3$. Healthy volunteers provided 3-4 six mm skin biopsies. Epidermal sheets were isolated and one was fixed immediately (TO) and the other was cultured in either EpiLife keratinocyte media control, conditioned media from healthy or late-onset psoriasis keratinocytes for

This article is protected by copyright. All rights reserved. 
$24 \mathrm{~h}$ before fixing. The LC frequency was determined for each epidermal sheet and shown for (c) EpiLife, (d) healthy keratinocyte conditioned media and (e) late-onset psoriasis keratinocyte conditioned media compared with the TO sample, each line represents data from one healthy individual ( $n=6-8)$. The significance of differences between T0 and T24 was analysed by paired t test ${ }^{* *} p<0.01, * * * p<0.001$. (f) The percentage LC migration data calculated as the percentage loss in the T24 epidermal sheet compared with the T0 epidermal sheet from the same sample. The significance of differences was analysed by one-way ANOVA followed by Tukey post test but differences were not significant.

This article is protected by copyright. All rights reserved. 
(a)

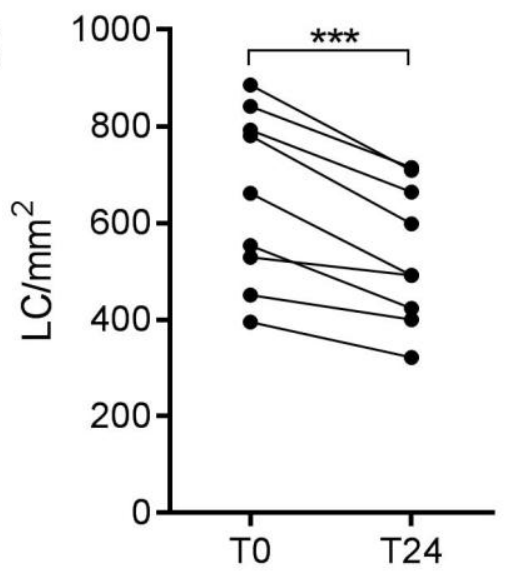

(c)

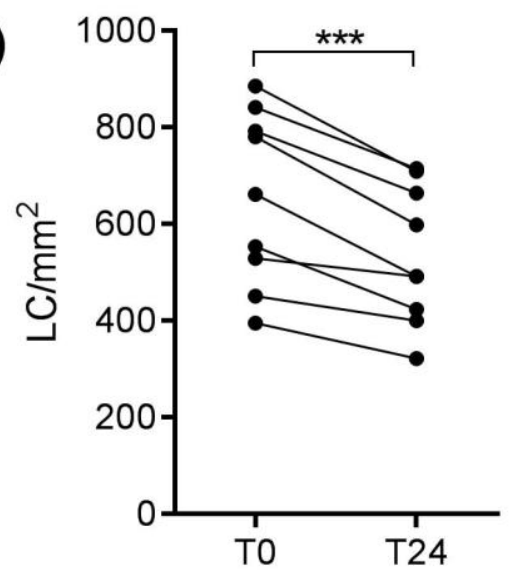

(e)

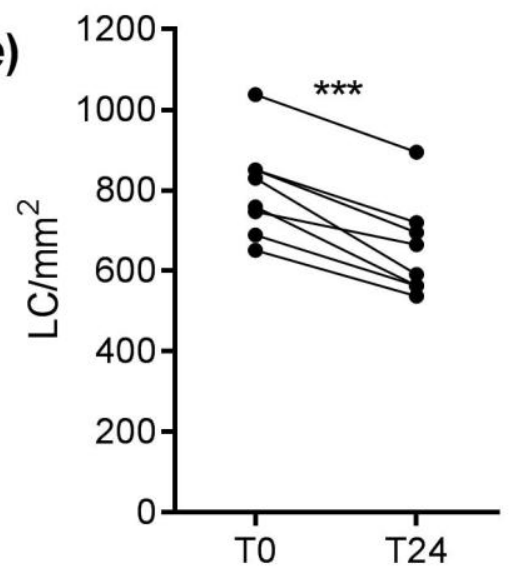

(b)

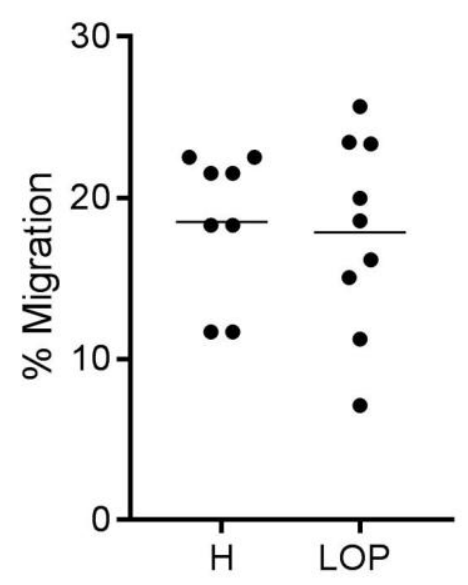

(d)

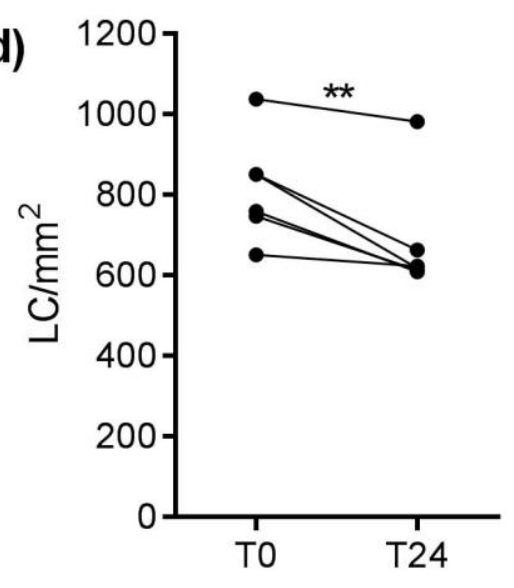

(f)

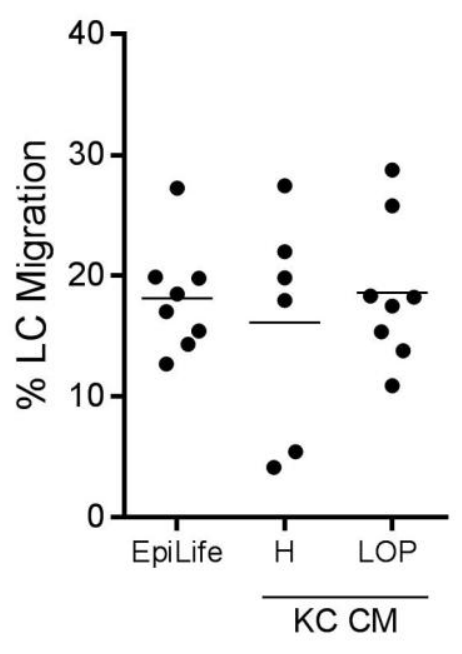

